\title{
KNOWLEDGE IN FOOD TOURISM: THE CASE OF LOFOTEN AND MAREMMA TOSCANA
}

\begin{abstract}
The aim of this paper is to contribute to a better understanding of knowledge in food tourism in agricultural and/or fishery areas. The presence and role of different types of knowledge are investigated adopting a multiple case study strategy in the regions Lofoten (Norway) and Maremma Toscana (Italy). The following types of knowledge are investigated: local and scientific food knowledge, tourism knowledge, local and global managerial and political knowledge.

The results from the case study indicate that scientific food knowledge and global managerial and political knowledge are particularly important in Lofoten. These types of knowledge are identified as the strengths on which a form of gourmet food tourism could develop. In Maremma Toscana, local food knowledge and local managerial and political knowledge are identified at the basis of the development of a generic form of food tourism. It is concluded that food tourism development requires different types of knowledge and their role is strictly dependent on the specific context. Any policy regarding food tourism should be based on the peculiarities of the specific terroir. Further research is required to investigate the tacit dimension of knowledge and those factors that can favour the establishment of global knowledge-based networks.
\end{abstract}

Keywords: food tourism; knowledge; collaboration; regional development 


\section{Introduction}

The term "food tourism" refers to a form of tourism in which food is one of the motivating factors for travel. This paper investigates to what extent different types of knowledge are present and the roles they can have in the development and management of food tourism in areas characterised by agricultural and fishery activities. The following research question is formulated:

Which types of knowledge are present in food tourism and what roles do they have in its development and management?

Four types of knowledge are identified:

- local food knowledge: about local food products, recipes and traditions,

- scientific food knowledge: about nutritional values and safety in the production, treatment, storage, transport and processing of food,

- tourism knowledge: about tourism as experience, valorisation of local resources and destination development and marketing,

- local managerial and political knowledge: about the socio-cultural aspects of the specific territory, in particular about the local social structures and collaboration patterns.

The development of the research question and the identification of the four types of knowledge are based on previous studies on tourism, knowledge management and rural development. The research question is focused on knowledge and intends to direct the investigation toward initiatives in food tourism at the regional level. The four types of knowledge identified are meant to cover important aspects of food tourism development. The idea is that a study of food tourism at the regional level, including different actors at different levels and focused on the presence of different types of knowledge and their roles, can potentially contribute 
to a way of understanding knowledge management in food tourism in accord with recent developments in knowledge management theory and practice.

The paper is organised in to four sections. The first section presents the background of this study. The second section describes the research method. In the third section the results of a multiple case study conducted in Lofoten (Norway) and in Maremma Toscana (Italy) are discussed. In the fourth section the conclusion is presented, summarising the results of the case study, outlining policy implications and limitations of the present study, and indicating directions for further research.

\section{Background}

The complexity of food as a phenomenon is reflected in the multidisciplinary nature of gastronomy, that includes the study of food production, treatment, storage, transport, processing, preparation, manners, psychology and traditions (Scarpato, 2002a). The broad spectrum of aspects objects of study by gastronomes illustrates that, in addition to its nutritional value, food has a cultural value: food is about identifying and communicating cultural expressions, about symbols and imagines of idealised realities (Richards, 2002; Tellstrom, Gustafsson, \& Mossberg, 2005). Food can be seen as the expression of a place's social and cultural capital, and, consequently, it can be a marker of local identities (Karlsson, 2005; Tellstrom, Gustafsson, \& Mossberg, 2005; Everett \& Aitchison, 2008). As a result, food can be an important element in tourism, assuming different roles, from being the peak experience, as in gourmet tourism, to being a complementary 
experience, as in rural tourism (Hall \& Sharples, 2003; Quan \& Wang, 2004). In any case, food, that is produced, sold and consumed in loco or taken home as a souvenir, assumes special meaning to the tourist. It has been claimed that eating can be perceived as absorbing the quality of the food and becoming part of a culture: for the tourist, eating local food can mean appropriating the nature, culture and identity of the specific area being visited (Bessière, 1998). In that regard urban food tourism commonly appeals to persons seeking a sophisticated lifestyle, while food tourism in rural areas appeals to persons seeking tradition (Hjalager, 1996; Richards, 2002).

\section{Food tourism in agricultural and fishery areas}

Due to the interconnection between food and local identity and culture, food tourism has substantial potential in terms of regional development. The territory, understood as the physical, socio-cultural and natural aspects of a specific region, plays a central role both in the production of food and in food tourism. Food Tourism Studies sometimes refer to this as terroir, and identify it as the element that gives food its distinctiveness and a region its touristic appeal (Hall, Mitchell, \& Sharples, 2003).

Economic activities such as small-scale agriculture and fishery can be connected to the concept of the multifunctionality, in that they provide food and can also produce other benefits, including becoming tourist attractions themselves (OECD, 2001; Van Huylenbroek \& Durand, 2003). Recent trends show that not-urban environments are among the preferred destinations for post-modern tourists, who often seek natural and cultural experiences that can give them a feeling of a return 
to purity (Bessière, 1998; OECD, 2002). As a result, agriculture and fishery, producing food and representing a particular lifestyle and set of values, can become important elements of a tourist destination marketing strategy (Scarpato, 2002b; Du Rand \& Heath, 2006).

In regard to its contribution to regional development, food tourism can lead to the following potential benefits: increased tourist expenditures, the creation of new job opportunities, the extension of the tourist season, the construction of infrastructures, the creation of a diverse cultural offer, the sustainment of the local environmental and cultural heritage, and, finally, the strengthening of identities, sense of self-assertion and belonging of local communities (Jamal \& Getz, 1995; Fincham \& Rhodes, 2005; Everett \& Aitchison, 2008). On the other hand, it has been observed that, especially in rural and peripheral areas, tourism - food tourism included - can negatively affect a region's development. It can damage natural and cultural heritage, have negative impacts on social structures and give low or no economic returns to the local population (Moscardo, 2008; Hall, Müller, \& Saarinenen, 2009).

In order to promote a form of tourism that can contribute to regional development, the concept of sustainable tourism as an adaptive paradigm has been developed and discussed in the last decade (Hunter, 1997; Moscardo, 2008). According to such a paradigm, food tourism in agricultural and fishery areas can be conceptualised as a possible developmental option based on the specific terroir. In such areas, regional development can be sustained combining economic activities across sectors, and, consequently, it requires the collaboration among different actors and the integration of different types of knowledge (Scarpato, 
2002b; Tovey \& Mooney, 2006; Saarinen, 2007; Kauppila, Saarineen, \&

Leinonen, 2009).

\section{Collaboration processes}

The combination of tourism with agriculture and fishery often involves a series of complex interactions among different actors, using existing networks and creating new ones (Brunori \& Rossi, 2000; Van der Ploeg, Renting, Brunori, Knickel, Mannion, Mardsen, de Roest, Sevilla-Guzman, \& Ventura, 2000; Van der Ploeg \& Roep, 2003; Briedenhann \& Winckens, 2004; Lee, Arnason, Nightingale, \& Shucksmith, 2005; Knowd, 2006).

Individual firms operating in agriculture and fishery are often small family businesses characterised by a household organisation: they enter the tourism business in response to difficulties arising from seasonal fluctuations, to the challenging conditions of the food markets and, in some cases, also as a lifestyle choice (Van der Ploeg, Renting, Brunori, Knickel, Mannion, Mardsen, de Roest, Sevilla-Guzman, \& Ventura, 2000; McGehee \& Kim, 2004; Bill 2007). In the agricultural context, business-related motivations and a sense of involvement and commitment toward the local community have been observed at the basis of small firms' choice to initiate or participate in cooperative actions (Tregear, 2005). In the tourist context, different approaches have been applied to study the phenomenon of individual firms cooperating in the development and management of a complete and high-quality tourist offer (Lazzeretti \& Petrillo, 2006). In food tourism literature, the term "networking" is sometimes used to refer to different forms of cooperative behaviour between organisations and households that are 
associated through economic and social relationships (Telfer \& Wall, 1996;

Cordigliano Antonioli, 2002; Hall, Mitchell, \& Sharples, 2003; Hall, 2005). As for other forms of tourism, the types of cooperative relations can be placed on a continuum where, to one extreme, coordination in the form of mutual adjustments indicates the most fragmented and informal relationships and, to the other extreme, strategic collaboration represents a more integrated relation (Jamal \& Getz, 1995). The latter may result in not only the success of a specific food product but also in a common certification process that guarantees its origin and quality, with the result of turning food in to a symbol of the local identity, and, consequently, in to an essential part of the destination marketing strategy (Ray, 1998; Hall, Mitchell, \& Sharples, 2003; Plummer, Telfer, \& Haimoto, 2006; Oukumus, Oukumus, \& McKercher, 2007; Tregear, Arfini, Belletti, \& Marescotti, 2007).

\section{Food tourism in a knowledge perspective}

Within collaborative processes in tourism, a crucial role is recognised to knowledge (Hjalager, 1996). Such an aspect can be illustrated referring to the position of Brunori and Rossi, who define the wine-route on which their case study is based as "an object of shared knowledge among a given set of actors" (Brunori \& Rossi, 2000: 419).

Although knowledge is identified as an important factor, a recent study has concluded that tourism scholars and practitioners have not adopted the new developments in knowledge management (Cooper, 2006). Some recent developments seem to be in the direction of an understanding of collaboration as a 
process characterised by continuous learning (Bramwell \& Lane, 2000). At the same time the recognition of the value of tacit knowledge and the shift of focus from the micro-level of individual firms to the macro-level of groups of firms, that recently have characterised other fields of study, seem not to be particularly represented in tourism (Cooper, 2006). Some authors consider the concept of knowledge as a resource to be shared across firms and, in some cases, across sectors through collaborative relations, as almost absent in tourism literature (Shaw \& Williams, 2009). Nevertheless, contributions that can be relevant for the study of food tourism in a knowledge perspective can be found in other fields of study. A useful classification of knowledge from Rural Studies distinguishes between scientific knowledge, political and managerial knowledge, and local knowledge (Csurgò, Kovách, \& Kuĉerová, 2008; Fonte, 2008). Scientific knowledge is a standardised form of knowledge deriving from research, and in the case of food it regards gastronomy. Political and managerial knowledge is about how to organise the production of food so that food becomes a competitive tourist product. Local knowledge is about "how things work": a technical form of knowledge about how to produce and prepare local food. In a knowledge perspective, food tourism development through networking among actors that detain different types of knowledge can be seen as a strategic choice for regional development. In this regard networking can contribute to the combination of traditions and modernity, that, allowing the actualization and reinterpretation of elements of the past, has been identified as a possible success factor for the construction and valorisation of local heritage (Bessière, 1998; Tregear, 2003). In addition, networking can provide the different types of 
expertise that are considered necessary in order to develop a sustainable form of tourism (Tovey \& Mooney, 2006).

The hierarchical model elaborated by Hjalager exemplifies the importance attached to knowledge and the integration of different types of knowledge (Hjalager, 2002). Four typologies of food tourism development are identified, corresponding to four degrees and types of cooperation and knowledge integration among the actors involved. In a first-order typology of development, food production is the main input resource and the tourist offer is based on existing economic structures, collaborative networks and knowledge. A second-order typology tends to create new collaborative structures, introducing changes and innovation in the material part of the production chain. Third-order development expands cooperation vertically, integrating production activities with service activities at the local level, and creating a complete tourism experience. Fourthorder development is based on different types of knowledge, scientific knowledge included, integrated through the establishment of networks at the global level. Though the tourism context has been described as particularly challenging, being characterised by the presence of many small firms typically concerned about loss of control, dependency on others, jealousies and little mutual trust in general, there is empirical evidence of collective initiatives among actors who detain different types of knowledge (Jamal and Getz 1995; Hjalager 2002; Cooper, 2006; Lazzeretti \& Petrillo, 2006). For example, the Slow Food movement, a worldwide network of food and wine interested actors organised in local groups, promotes the integration of different types of knowledge through cooperative and collaborative relations (Petrini, 2003). In this sense particularly significant is the case of the establishment, together with the public administrations of Piedmont 
and Emilia Romagna, of the University of Gastronomic Sciences (Slow Food, 2010).

\section{Method}

A case study strategy is adopted in order to answer the research question: Which types of knowledge are present in food tourism and what roles do they have in its development and management?

Recent studies in food tourism indicate that case studies can effectively identify relevant issues and important driving forces of the processes involved (Everett \& Aitchison, 2008). The adoption of a case study strategy involves two challenges: overcoming an anecdotal characteristic, and identifying contextual conditions that are significant for the research question (Hjalager \& Richards, 2002; Yin, 2003). These challenges were faced by conducting a multiple case study in two tourist destinations: Lofoten (Norway) and Maremma Toscana (Italy). The adoption of a multiple case study limits the risk of gaining insights specific to a given situation: as a result it is a more robust research strategy than a single case study (Yin, 2003). The logic underlying the choice of the destinations is a mix of literal and theoretical replication (Yin, 2003). Food tourism is present in both destinations and these can be seen as similar in regard to: their economic context traditionally dominated and still heavily influenced by primary sector activities, their relative geographical isolation and their relatively well-known reputation in tourism. The results from the two cases are predicated to be similar in the sense that knowledge is expected to be a critical factor, present in its different types in food tourism 
initiatives in both cases. At the same time some differences are expected due to the fact that food culture and food tourism are relatively new phenomena in Norway, Lofoten included, while food culture is a well-integrated part of the Italian culture and Tuscany is among the regions with many years of experience in food tourism. The limitation to Maremma within the Tuscan case is based on the fact that this area is characterised by the importance that the primary sector, mainly agriculture, has had in the past and still has today, and by the absence of famous tourist magnets.

In order to achieve the research objectives of accuracy and complexity, a variety of sources and collection methods were applied (Yin, 2003; Beeton, 2005; Woodside, 2010). A qualitative methodological approach consisting of gathering a combination of secondary and primary data was adopted. A review of academic publications and reports was conducted. Additional secondary data were collected, more specifically: promotional material, official reports and documents produced by public, semi-public and private agencies working in the field of tourism and/or food production and promotion. A content analysis of these data was conducted focusing on the following topics: the presentation of food related tourism products, their role as part of the tourism experience of the specific destination and as part of the local economy. Based on the results of the secondary data collection and analysis, two informants were identified: the leader of Destination Lofoten, the agency for the promotion of tourism in Lofoten, and the leader of Turismo Verde, the tourism section of one of the main farmers' associations in Maremma Toscana. Such informants indicated the first contacts to arrange the fieldwork. The collection of primary data and of some supplementary secondary data took place during a total of four weeks of fieldwork, performed in the period 
from June to October 2009, in the neighbouring municipalities of Vågan and Vestvågøy in Lofoten and in the province of Grosseto in Maremma Toscana.

Primary data were collected through observations and informal and semistructured interviews. Observations took place in June and August 2009 in Lofoten, and in July and October 2009 in Maremma. A list over the interviews is presented in table 1.

Table 1. Interviews.

\begin{tabular}{|c|c|c|c|}
\hline INTERVIEWS & $\begin{array}{l}\text { Main sector } \\
\text { of activity }\end{array}$ & \begin{tabular}{|c|} 
Number \\
of respondents
\end{tabular} & $\begin{array}{c}\text { Code in the } \\
\text { paper }\end{array}$ \\
\hline \multirow[t]{2}{*}{ Lofoten, June 2009} & tourism & 5 & RESP 1, 2, 3, 4, 5* \\
\hline & food & 5 & $\mathrm{RESP}^{* *}, 7,8,9,10$ \\
\hline \multirow[t]{3}{*}{ Maremma T., July 2009} & tourism & 4 & RESP $11^{*}, 12^{*}, 13,14^{*}$ \\
\hline & food & 2 & RESP $15,16^{*}$ \\
\hline & rural development & 1 & RESP 17 \\
\hline
\end{tabular}

A total of 17 respondents whose activities were food and tourism related were interviewed. Most of the interviews were face-to-face, in the mother language of the interviewees, and were recorded and transcribed, with the exceptions reported in the table. In some parts of the paper identification codes are used in order to guarantee a certain degree of anonymity. 


\section{Food tourism in Lofoten and in Maremma Toscana}

The following two sub-sections describe food tourism in Lofoten and in

Maremma Toscana and are based mainly on secondary data. The third sub-section discusses the presence and the roles of different types of knowledge. The discussion is based on secondary and primary data, and on a classification of knowledge and cooperation as emerged in previous studies, in particular in Csurgò, Kovách, \& Kuĉerová (2008), Fonte (2008) and Hjalager (2002).

\section{Food tourism in Lofoten}

Lofoten is a tourist destination characterised by pristine, spectacular nature. It consists of a group of islands in front of the Norwegian coast north of the Arctic Circle. Part of the Nordland County, Lofoten is composed of six municipalities, for a total of $1,227 \mathrm{~km}^{2}$ and some 23,000 inhabitants.

Fishery and related activities, especially the production and export of dry cod, have traditionally been the main source of income (Holmefjord, 2000). Various forms of household based pluriactivity that combine fishery with agriculture and the multifunctionality of agriculture are not new phenomena in Norway (Eikeland \& Lie, 1990; Daugstad, Ringdal, Rønningen, \& Skar, 2002; Rønningen, Fjeldalvi, \& Flø, 2005; Brox, 2006; Daugstad, Rønning, \& Skar, 2006). The tourist industry in Lofoten has experienced considerable growth in the last few decades, although it is subject to great seasonal fluctuations, with a peak season around July (Jacobsen, Grue, \& Haukeland, 2002). It is just recently that food culture, local food and rural lifestyle have started to be valued and considered to be potential 
tourist attractions in Norway (Amilien \& Stø, 2000; Daugstad, 2005). In this regard, cooperation and knowledge have been identified by Norwegian researchers as being critical success factors (Amilien \& Stø, 2000; Forbord \& Stræte, 2008).

Due to this recent trend in food culture, several actors are working toward turning Lofoten into what is called a "food region". Synergies between the primary sector and tourism activities have become relatively common in the last years. One example is the presence in Lofoten of three farms that belong to "The Rooster", a national organisation operating in farm-tourism, including the production and sale of local food (http://www.hanen.no/). Another example is the presence of three restaurants belonging to the "Arctic Menu" project, a northern Norwegian network of eating establishments that serve food prepared with local ingredients (http://www.arktiskmeny.no/). Two examples of organisations that recognise food as playing a crucial role in the cultural context of Lofoten are the Viking Museum and LofotFood. In 1995 the Viking Museum started to use traditional food as an important part of the tourist experience (http://www.lofotr.no/). LofotFood is a small local firm driven by two professional cooks who occasionally work at local restaurants, organise catering, courses and lectures using local ingredients, both in traditional recipes and innovatively (http://www.lofotmat.no/). Even if examples of activities based on an understanding of food that goes beyond nutritional value and that includes cultural aspects can be found, food tourism is still considered to be at a developmental stage (Jacobsen, Grue, \& Haukeland, 2002; Destination Lofoten AS \& Lofotrådet, 2008). In 2006 the LofotCouncil, a council representing the six municipalities in Lofoten, and Destination Lofoten, the regional marketing office for the promotion of Lofoten as a tourist destination, have formulated a 
strategic plan for tourism destination building (Destination Lofoten AS \& Lofotrådet, 2008; LofotenMat BA, 2008). Synergies between tourism and the primary sector are considered of paramount importance, in particular alliances among fishermen, farmers and actors from the cultural sector. The strategic plan identifies food tourism as one of its main goals, as illustrated with the slogan "Food from Lofoten on the tourists' plate" (Destination Lofoten AS \& Lofotrådet, 2008: 43).

An analysis of promotional material reveals that food is presented on some brochures and leaflets available at the local tourist offices, but is not prevalent in the official web-pages, for example Destination Lofoten's web-page (http://www.lofoten.info/). On the other hand, food occupies an important position in the presentations many private businesses give on their own web-pages, for example the section dedicated to the restaurant of Kræmmervika hotel (http://www.kremmervika.no/). Information on food-related events is included on the web-page of LofotenFood (http://www.lofotenmat.no/). LofotenFood is a local organisation of private and public actors that promotes food as a tourist attraction, organising food-related activities, such as seminars and workshops (LofotenMat BA, 2008). The bigger food events take place in the period of August-September, such as the "Naturally Food Festival" in Leknes (http://www.lofothallen.no/matfestival/), the "International Food Festival" in Svolvær (http://www.lofoten-matfest.no/) and the "International Dry Cod Festival" in Henningsvær (http://www.litf.net/). Relations with international entities are promoted by LofotenFood and public entities, such as the Vågan municipality: an example is the relations with the Italian town of Ancona, with which cooperative projects have been carried out in the past and are planned for 
the future. Other international relations are present, such as the "Cap of the North" project, which includes several culinary workshops with actors from Finland, Sweden and Norway (REF 10). In addition, several contacts are being established through the Slow Food Lofoten network (http://lofoten.wordpress.com/).

\section{Food tourism in Maremma Toscana}

Tuscany is a tourist destination famous both for its culture and landscape. The multifunctionality of agriculture has shaped the recent developmental path of Tuscany, characterised by reproducing old values, both environmental, social and cultural ones, in a new form that is suitable for today's society (Di Iacovo, 2003). Tuscany is among the Italian regions where, based on a multifunctional model, the establishment of local systems, territorial agricultural systems, agro-food and rural districts has taken place in the latest 60 years (Brunori, Rossi, \& Bagnoli, 2005). Agro-tourism and food tourism are well-established forms of tourism with different characteristics according to their specific territory (Balestrieri, 1996; Hausmann \& Di Napoli, 2001; Belletti, Brunori, Marescotti, \& Rossi, 2003; Sonnino, 2004). The case of typical products, certificated local food products, is a prime example of the results of cooperation among a plurality of actors of the specific area (Belletti, Brunori, Marescotti, \& Rossi, 2003).

Maremma Toscana is an area that approximately coincides with the province of Grosseto in southern Tuscany, for a total of 4,504 $\mathrm{km}^{2}$ with some 223,000 inhabitants. In the past two decades, investments in economic activities across sectors, with agriculture playing a central role, have taken place with the establishment of the Rural District of Maremma, a local territorial system of 
collaboration (Balestrieri, 1998; Pacciani, 2003; Toccaceli, 2006; Di Napoli, 2007). The crucial role of food production is evident from the recent project initiated by the province of Grosseto to set up a food production research centre focused on quality and safety (Provincia di Grosseto, 2009). In terms of tourism, Maremma belongs to "Minor Tuscany", which is characterised by the lack of global tourist magnets, such as Florence and Siena or the Chianti area, and by a natural environment that varies from farmland to protected areas (Balestrieri, 1996; Balestrieri, 1998; Pagni, 2002).

Promotional material presenting food as a tourist attraction can easily be found in any tourist office of the area and on the internet. Sections dedicated to typical food products are present on the web-pages of promotional organisations, of private hoteliers and travel agencies, and on the official web-site of the province of Grosseto. An example is the section dedicated to food and wine on the web-page of one of the farmers' association operating in the area (http://www.agriturismoverde.com/). The province of Grosseto is the main public entity that promotes and supports food tourism, especially in the form of cooperation between public entities at the local and regional level, the different municipalities, local farmer associations, tourist actors, and cultural organisations. The Province also coordinates projects promoted and financed by the European Community. The official tourist office is the Maremma Agency for Tourism: its web-page provides information about local gastronomy and a list over 60 tourist associations operating in the area, among which is Slow Food Grosseto (http://www.lamaremmafabene.it/). Most of the associations have web-sites where they present the services offered to members, and they promote Maremma as a destination that is particularly attractive for its natural environment and the 
cultural life characterised by small centres. Food is presented as part of the tourist experience Maremma can offer: in some cases this is done by giving information about the typical local products, in other cases announcing specific food events. Many of the food events promoted are sagre: food festivals organised around one or a few local products or recipes. About 90 sagre take place in the province of Grosseto year-round (RESP 12). Gustatus is a four-day food festival that integrates food with other cultural events, such as food related conferences (http://www.gustatus.org/). It involves many local public and private entities, including the local Slow Food section (http://www.slowfoodtoscana.it/condotta_grosseto.htm). Some associations specialise in tourist routes promote local products as well as local producers and are present in Maremma as part of a bigger project at the regional level promoted by the region Tuscany (http://www.terreditoscana.regione.toscana.it/stradedelvino/). In particular three are the tourist routes in the area: Montecucco Wine Route and Taste Route of Amiata, Wine and Flavour Trail of the Maremma Hills and Wine Route and Taste Route of Montereggio. Special attention is given to certified products, such as D.O.C. wines, and to producers that use methods defined as biological and/or socially responsible. In addition to food festivals, other food-related activities are promoted: many leaflets that can be found at local tourist offices promote visits to wine cellars, farms, farmers' markets, and cooking courses. A particular interesting project is "Art and Food" (http://filieracorta.arsia.toscana.it/UserFiles/File/Filiera\%20corta/Arte\&CiboGR.p df). It is promoted by the region Toscana, the province of Grosseto and many other local actors as part of a bigger project that promote local agriculture: it is 
held from May to November and consist of a series of events that integrate local food initiatives, such as wine tasting, with several different types of cultural experiences, such as theatre, visits to museums and excursions.

\section{Discussion: knowledge in food tourism}

The following discussion adopts a classification of knowledge as emerged in previous studies, in particular in Csurgò, Kovách, \& Kuĉerová (2008) and Fonte (2008). Local and scientific food knowledge, tourism knowledge, and local managerial and political knowledge are discussed, first individually and then focusing on their co-existence. Hjalager's model is adopted to discuss the degree and type of cooperation and knowledge integration. Finally the results of the case study are summarised with the help of a graphical illustration.

\section{Types of knowledge}

The case study shows the presence of different types of knowledge in food tourism initiatives, both in Lofoten and Maremma Toscana. In Lofoten food knowledge is present, especially in the form of scientific knowledge. Results from interviews conducted and observations gained during the fieldwork in Lofoten have shown the presence of many individual operators, especially chefs, who detain food knowledge and work actively to valorise local and traditional food (RESP 2; RESP 3; RESP 6; RESP 7; RESP 8; RESP 9; RESP 10). An example that illustrates the cultural and educational role recognised to food by some of the local actors is the following reflection made by the manager of a small firm that arranges catering and food lessons: 
"It seems one generation, today's teenagers and young people, has no knowledge about local culinary traditions, but we can still educate today's children. I think their parents are interested in gaining back their traditions. It's part of our history and identity that we need to create our future." (RESP10)

As a consequence of this belief, the specific firm is very active in the promotion food knowledge, both in its sophisticated form and its more popular form. In Maremma the knowledge of local food is very common. This aspect was explicitly commented during some interviews (RESP 11; RESP 12). Observations revealed the presence of local food in restaurants, specialised shops and supermarkets. Also the numerous sagre demonstrate the popularity of food culture. The presence of scientific food knowledge is less evident, but still important, as demonstrated by the Wine and Taste Routes.

Observations show that, both in Lofoten and Maremma, many of those who detain food knowledge also believe in food as a potential tourist attraction. This aspect was outlined also from some of the respondents (RESP 7; RESP 8; RESP 10; RESP 15; RESP 16). These are practitioners who promote local food individually, as in the case of restaurants, and also collectively, joining networks such as the "Arctic Menu" in Lofoten and the "Art and Food" project in Maremma. Results from the fieldwork show also a relatively common understanding of tourism as an experience that, in order to be high-quality, can be improved through collaboration. In Lofoten this understanding of tourism is evident among those who contributed to the tourism destination building plan: LofotenFood, Destination Lofoten, and the six municipalities of Lofoten. In particular LofotenFood identifies collaborative networks as a critical element and works 
actively for it. Meetings among different actors, including those who do not belong to the same territory but share the same field of practice, are promoted by both private and public entities, such as Slow Food Lofoten and the Vågan municipality. Reflecting on how networking seems to be perceived by the local practitioners, especially farmers, a respondent who works actively for the establishment of cooperative relations said:

"We see some of the local people begin to believe that we need to think in an innovative way, in order to survive (...). There is now a kind of generation shift, the focus is on product development. This creates an active milieu." (RESP 9)

Also interviews revealed that several Lofoten actors recognise the importance of networking: some respondents clearly indicated that working together is a very good way to share valuable experiences and learn from each other (RESP 7; RESP 8; RESP 10). The same respondents identified possible barriers to collaborative practices: mainly the lack of time to nurture relationships, due to busy schedules, and personal conflicts. During an interview at a farm a respondent noted:

"Without already existing networks, it would be difficult for me to find other people with the same interests and with whom I could cooperate, as I'm busy all the time doing this (showing the basket of aromatic herbs she's preparing) and much more!" (RESP 7)

Another respondent working at a restaurant noted:

“The networks can be useful to meet people but at the end it's all about chemistry, whether you find a potential partner or not." (RESP 3) 
According to LofotenFood, other barriers can emerge from a different and less integrated way of understanding tourism, and from financial resources that limit the number and type of collaborative initiatives.

The situation in terms of collaboration in Maremma is characterised by the public entities that promote and sometimes are the driving force behind food projects, and by the associations of farmers and tourist actors. Field interviews show that the same elements perceived as barriers to collaboration in Lofoten are also present in Maremma (RESP 11; RESP 13; RESP 15). During an interview, a respondent working for a farmer's association commented:

"For some people it's difficult to think in a broad way, they are concerned and very busy with their own business. We have to "push them" in the right direction, and then, they see it, at least some of them... The worst is when personal conflicts stay on the way of cooperation, sometimes due to political belonging". (RESP 11)

Although the importance of networking and collaboration is recognised and has inspired projects and events in Lofoten, it seems that it is not conceptually and effectively included in the broader context of tourist destination building and regional development, as it is in Maremma. According to the public entities operating in Maremma, food initiatives based on a combination of different types of knowledge, such as the Wine and Taste Routes, can contribute to regional development when they are included in a broader project, and the establishment of the Rural District has contributed to opening toward a culture of collaboration that can support this kind of development. In this regard a respondent from the public administration in Grosseto commented: 
"All the initiatives at the local level benefit from the existence of the Rural District. This way of thinking about our territory makes things easier, there are still conflicts and lots of challenges but still...we have a common language."

\section{(RESP 17)}

The sense of community in terms of collaboration for a common interest and identity influences the food product certification processes. In Lofoten, LofotenFood considers the certification process as being crucial, but interviews show that this view is only partly shared by local operators; most of the respondents considered food certification to be important and some are working actively toward it, but some respondents failed to recognise it as a critical factor, and viewed it as a long and complicated process that should be managed at a higher level, if at all (RESP 6; RESP 7; RESP 8; RESP 10). Results from fieldwork in Maremma show a broader acceptance of the notion that food certification as a crucial element. As a respondent of a local tourist association said about the process leading to the adoption of certification:

"Some firms are better than others to be innovative, we have one here in the area, he's really good, always interested in doing things better (...), also in regard to certification about the environmentally friendly processes they use and quality. Then the others see it and understand it's the way to go ... maybe slowly ... at the end new ideas get popular, like it's now becoming for certification." (RESP 13)

In terms of tourism and local managerial and political knowledge, the Norwegian and Italian experiences presented at a seminar at the "International Food Festival" in Svolvær in 2009 are interesting. Collaboration was clearly identified as a critical success factor by both sides. The Italian participants showed examples of 
practical tools that have been used for a relatively long period of time to create networks. Among these the experience of the Rural District of Maremma, even if not cited at the seminar, could be inserted. Moreover, the certification process and in general the centrality of terroir were discussed: their relevance as elements that can give a tourist destination a unique profile was recognised by both sides, with the difference that the Italian participants could refer to a longer period of experience.

\section{Roles of knowledge}

The case study shows not only the presence, co-existence and integration of different types of knowledge, but also the different roles that these can play according to their context. Food knowledge is essential for food tourism. It is the characteristics of food knowledge, for example whether it is held mainly by a small group of experts, as in Lofoten, or by a broad group of amateurs, as in Maremma Toscana, that, together with other socio-cultural aspects of the specific territory, influence a region's current and potential form of food tourism. Food knowledge in Lofoten can play a crucial role in the re-discovery and transmission of local food traditions, especially to the younger generations. In this sense it can be at the basis of a sustainable development, that has among its basic assumptions the socio-cultural reality of the host community and its contribution to the region's development. In addition, scientific food knowledge can contribute to the shaping of a developmental trajectory of food tourism pointing toward a sophisticated gourmet experience expression a post-modern lifestyle. This is usually characteristic of urban areas, but it may be a viable strategy for Lofoten. In Maremma food knowledge is actively used in every-day life. It is usually 
transmitted to the younger generations within the family structure and to tourists in the form of meals served in restaurants and cooking courses. Food from Maremma is associated with elements of genuineness and quality, and this contributes to the traditional rural profile of Maremma as a tourist destination, as promoted on the marketing material. Consequently, also scientific food knowledge in Maremma promotes these typically rural aspects instead of the more sophisticated ones.

In terms of tourism knowledge, Maremma competes with more famous Tuscan areas. It may be said that the competitive strategy for Maremma is clearly set in terms of tourist destinations, and thinking tourist destination building for Maremma is almost a consequence of the context Maremma is situated in. The challenging situation of Lofoten is more in terms of seasonal fluctuations than in terms of competing tourist destinations. Accordingly, the tourist destination thinking is less rooted in the local way of thinking in Lofoten than in Maremma. At this phase of food tourism development, the main function of tourism knowledge in Lofoten is to turn food into a tourist attraction. Even though some tourist destination building is evident, it seems that practices in this sense are more likely to result in a second developmental phase.

The tourist destination aspect is strictly related to local managerial and political knowledge. In Maremma the knowledge behind most of the collective initiatives in food tourism is mainly held by local public actors and private associations of farmers and tourist actors. The existence of the Rural District is an expression of the presence of this type of knowledge: it brings together different actors, from businesses to the research milieu, with the result of providing coherence to the different initiatives and contributing to the quality of the products and services 
offered and, at the same time, to the quality of life of the host community. In Lofoten the role played by local managerial and political knowledge is significant and can be observed in the involvement of local organisations and local public entities. At the same time also networking beyond the local context, a form of global managerial and political knowledge, is present in several projects and events.

\section{Food tourism development typologies}

Adopting Hjalager's model, food tourism development in Lofoten seems to have important characteristics that are typical of different typologies. In particular the recognition of the need to turn food in to a tourist attraction seems to qualify the development as a first-order typology. At the same time collaborative relations that go behind the local area are established and form a sort of global knowledgebased network, that, according to Hjalager's model, are typical of fourth-order development. This aspect can be explained by the local willingness and capacity to create contacts at the international level. This element raises interesting questions about the relevance of a global form of managerial knowledge, a type of knowledge that might be of particular significance for geographically peripheral and sometimes socially isolated areas, and that is more feasible with today's advances in ICT than it was some years ago. The existence of a Slow Food section, with its on-line meeting arena and its broad spectrum of members from different countries, has been important for the creation of a sort of community and the formation of relations.

In the case of Maremma, food tourism has developed along a continuous path in correspondence of a strong food culture, and at the moment presents 
characteristics of the third-order typology. The existence of a Rural District, that supports food tourism with an already developed and broad network among practitioners, local public actors and research milieu, with the result of creating a common platform for cooperation, results to be crucial.

\section{A graphical illustration of knowledge in food tourism}

The results of the case study can be summarised and illustrated graphically with a profile for each case (fig. 1).

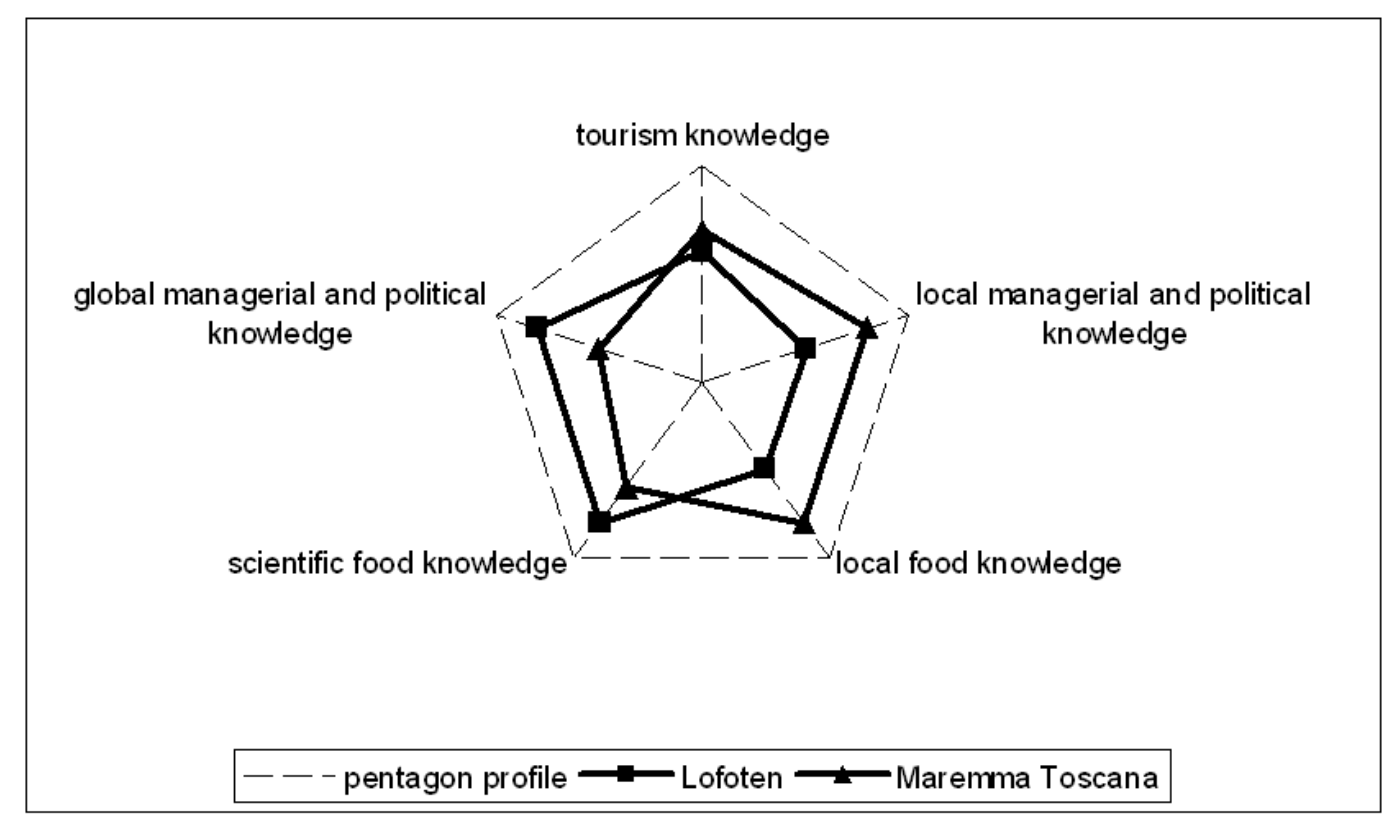

Figure 1. Types of food knowledge in Lofoten and Maremma Toscana.

The profile showed in fig. 1 is obtained evaluating the presence of each types of knowledge on a scale, and uniting the five points, within the area of a regular pentagon. The choice to illustrate the results from the cases in such a diagram responds to the purpose of representing the different types of knowledge as complementary. The profiles of the regions show which types of knowledge food tourism can be built on, and, together with considerations about the specific 
terroir, it can give an indication about the form of food tourism to promote, the target-group of interest, and, eventually, whether food tourism is a realistic developmental path.

\section{Conclusion}

The results from the case study show that in addition to local and scientific food knowledge, tourism knowledge and local managerial and political knowledge, also a form of global managerial and political knowledge can play an important role. The presence of such a form of knowledge, together with scientific food knowledge, is crucial for the development of food tourism in Lofoten. This element, together with considerations about the vulnerability of the natural environment, indicates a form of sophisticated gourmet tourism as a viable path for the region. In the case of Maremma, local food knowledge and local managerial and political knowledge are identified as the strengths of the region. A generic form of rural food tourism may that appeal to a relatively broad spectrum of tourists can be regarded as possible developmental option for this area. The present study has limitations in terms of generality. The results from the case study show that the roles of different types of knowledge depend on the local terroir, and, as a consequence, any policy regarding food tourism should be based on the peculiarities of the specific region.

Further research is required to investigate the tacit dimension of knowledge. For this purpose, longitudinal studies including participant observations may be an opportune design, contributing also to improve the achievements in terms of 
research accuracy and complexity. In order to gain more insights in the type and the role of knowledge in food tourism, more cases could be investigated.

Particularly interesting can be the cases where ICT is diffused among the different actors to such a degree that can potentially be relevant for the establishment of global knowledge-based networks. 


\section{References}

Amilien, V., \& Stø, E. (2000). Om matkultur... et felles SIFO-arbeid på oppdrag av Statens Landbruksbank, Arbeidnotat nr. 19.2000, Lysaker: Statens Institutt for Forbruksforskning. Retrieved from SIFO web-site:

http://www.sifo.no/page/Publikasjoner//10081/53571.html

Balestrieri, G. (1996). La filiera dell'agriturismo: dal successo nelle aree agrituristicamente "forti" ai tentativi di decollo nelle aree svantaggiate. In A. Pacciani, G. Belletti, L. Giancani, A. Marescotti, \& S. Scaramuzzi (Eds.). Agricoltura toscana e sistema agroindustriale. Caratteristiche strutturali e rapporti organizzativi. Firenze: INEA.

Balestrieri, G. (1998). L'agriturismo toscano tra crescita autonoma e promozione pubblica. Strutture e dinamiche nel sistema agro-industriale toscano. In A. Pacciani, G. Belletti, L. Giancani, A. Marescotti, \& S. Scaramuzzi (Eds.). Agricoltura toscana e sistema agroindustriale. Caratteristiche strutturali e rapporti organizzativi. Firenze: INEA.

Beeton, S. (2005). The Case Study in Tourism Research: a Multi-method Case Study Approach. In B. W. Ritchie, P. Burns, \& C. Palmer (Eds.)._Tourism Research Methods. Integrating Theory with Practice. Wallingford: CABI Publishing.

Belletti, G., Brunori, G., Marescotti, A., \& Rossi, A. (2003). Multifunctionality and rural development: a multilevel approach. In G. van Huylenbroeck, \& G. Durand (Eds.). Multifunctional agriculture: a new paradigm for European agriculture and rural development? Aldershot, Ashgate.

Bessière, J. (1998). Local development and heritage: Traditional food and cuisine as tourist attractions in rural areas. Sociologia Ruralis, 38(1): 21-34.

Bill, F. (2007). Experiencing the dairy: unlocking the value of peripheral traditions. In D. Hjorth, \& M. Kostera (Eds.). Entrepreneurship \& the Experience Economy. Copenhagen Business School Press.

Bramwell, B., \& Lane, B. (2000). Tourism Collaboration and Partnerships. Politics, Practices and Sustainability. Aspects of Tourism: Channel View Publications.

Briedenhann, J., \& Winckens, E. (2004). Tourism routes as a tool for the economic development of rural areas - vibrant hope or impossible dream? Tourism Management, 25, 71-79.

Brox, O. (2006). The Political Economy of Rural Development. Modernization without Centralization? Delft, Eburon Publishers. 
Brunori, G., \& Rossi, A. (2000). Synergy and Coherence through Collective Action: Some Insights from Wine Routes in Tuscany. Sociologia Ruralis, 40(4), 409-423.

Brunori, G., Rossi, A., \& Bagnoli, S. (2005). Multifunctionality of activities, plurality of identities, and new institutional arrangements. Italian state of art. University of Pisa, Multagri Project.

Cooper, C. (2006). Knowledge Management and Tourism. Annals of Tourism Research, 33(1), 47-64

Cordigliano Antonioli, M. (2002). The route to quality: Italian gastronomy networks in operation. In A.-M. Hjalager, \& G. Richards (Eds.). Tourism and Gastronomy. London, Routledge.

Csurgò, B., Kovách, I., \& Kuĉerová, E. (2008). Knowledge, power and sustainability in contemporary rural Europe. Sociologia Ruralis, 48(3), 292-312.

Daugstad, K. (2005). When the farmer becomes a provider of landscapes and agri-tourism and the tourist wants to be part of "real rural life". A story of insiders and outsiders in the Norwegian landscape. Trondheim: Centre for Rural Research. Retrieved from http://www.bygdeforskning.no/dynamisk/Publikasjoner_PDF/PAPER\%2008.05.p $\underline{\mathrm{df}}$

Daugstad, K., Ringdal S., Rønningen, K., \& Skar, B. (2002). Agriculture and cultural heritage. A state of the art report on research based knowledge. Trondheim: Centre for Rural Research. Retrieved from http://www.bygdeforskning.no/dynamisk/Publikasjoner_PDF/RAPPORT\%2007.0 2.pdf

Daugstad, K., Rønningen, K., \& Skar, B. (2006). Agriculture as an upholder of cultural heritage? Conceptualizations and value judgements- A Norwegian perspective in international context. Journal of Rural Studies 22, 67-81.

Destination Lofoten AS, \& Lofotrådet (2008). Lofoten som reise mål mot 2015. En Masterplan for arbeidet med bedre reisemålsutvikling $i$ Lofoten.

Di Iacovo, F. (2003). New trends in the relationship between farmers and local communities in Tuscany. In G. van Huylenbroeck, \& G. Durand (Eds.). Multifunctionality: a new paradigm for European agriculture and rural development? Aldershot, Ashgate.

Di Napoli, R. (2007). LEADER e distretti rurali. Sinergie e complementarieta'. Rete LEADER. Retrieved from: http://www1.inea.it/file_bollettino/8_WPdistretti.pdf

Du Rand, G.E., \& Heath, E. (2006). Towards a Framework for Food Tourism as an Element of Destination Marketing. Current Issues in Tourism, 9 (3), 206-234 
Eikeland, S., \& Lie, I. (1990). Pluriactivity in rural Norway. Journal of Rural Studies, 5, 405-415.

Everett, S., \& Aitchison, C. (2008). The Role of Food Tourism in Sustaining Regional Identity: A Case Study of Cornwall, South West England. Journal of Sustainable Tourism, 16(2), 150-167.

Fincham, R., \& Rhodes, P.S. (2005). Principles of organizational behaviour. Oxford: Oxford University Press.

Fonte, M. (2008). Knowledge, food and place. A way of producing, a way of knowing. Sociologia Ruralis, 48(3), 200-222.

Forbord, M., \& Stræte E.P. (2008). Hva betyr reiseliv, kultur og lokal mat for omsetning og sysselsetting i distriktene? Trondheim: Centre for Rural Research. Retrieved from http://www.bygdeforskning.no/filarkiv/2008/04/16/14805a6fc671e0.pdf

Hall, C. M., Mitchell, R., \& Sharples, L.(2003). Consuming places: the role of food, wine and tourism in regional development. In C. M. Hall, L. Sharples, R. Mitchell, N. Macionis, \& B. Cambourne (Eds.). Food tourism around the world: development, management, and markets. Elsevier.

Hall, C. M., Müller, D. K., \& Saarinenen, J. (2009). Rural Tourism: Tourism as the Last Resort?. In C. M. Hall, D. K. Müller, \& J. Saarinen (Eds.). Nordic Tourism: Issues and Cases. Bristol: Channel View Publications.

Hall, C. M., \& Sharples L. (2003). The consumption of experiences or the experience of consumption? An introduction to the tourism of taste. In C. M. Hall, L. Sharples, R. Mitchell, N. Macionis, \& B. Cambourne (Eds.). Food tourism around the world: development, management, and markets. Elsevier.

Hall, C. M. (2005). Rural Wine and Food Tourism Cluster and Network Development. In D. Hall, I. Kirkpatrick, \& M. Mitchell (Eds.). Rural Tourism and Sustainable Business. Clevedon: Channel View Publications.

Hausmann, C., \& Di Napoli, R. (Eds.). (2001). Lo Sviluppo Rurale. Turismo rurale, agriturismo, prodotti agroalimentari. Quaderno Informativo $\mathrm{nr} 4$. INEA. Retrieved from: http://www1.inea.it/reteleader/pubblica/quaderni/quaderno4-2.pdf

Hjalager, A.M. (1996). Agricultural diversification into tourism. Evidence of a European Community development programme. Tourism Management, 17(2), 103-111.

Hjalager, A.M. (2002). A typology of gastronomy tourism. In A.M. Hjalager, \& G. Richards (Eds.). Tourism and Gastronomy. London: Routledge

Hjalager, A.M., \& Richards, G. (2002). Still undigested: research issues in tourism and gastronomy. In A.M. Hjalager, \& G. Richards (Eds.). Tourism and Gastronomy. London: Routledge 
Holmefjord, K. (2000). Linking products, industries and place-synergy effects from the interaction of tourism and other local industries in Lofoten and Hardanger. SNF Prosject No. 6490 Image av norske reisemål. Bergen Foundation for Research in Economics and Business Administration. Retrieved from http://bora.nhh.no/bitstream/2330/1348/1/A85_00.pdf

Hunter, C. (1997). Sustainable tourism as an adaptive paradigm. Annals of Tourism Research, 24(4), 850-867.

Jacobsen, J. K. S., Grue, B., \& Haukeland, J. V. (2002). På veg mot drømmeferie? Aktiviteter, interesser og opplevelser blant utlandske bil turister $i$ utvalgte område i Norge. ТØI. Oslo.

Jamal, T. B., \& Getz, D. (1995). Collaboration theory and community tourism planning. Annals of Tourism Research, 22(1), 186-204.

Karlsson, S. E. (2005). The Social and the Cultural Capital of a Place and their Influence on the Production of Tourism - A Theoretical Reflection based on an Illustrative Case Study. Scandinavian Journal of Hospitality and Tourism, 5(2), 102-115.

Kauppila, P., Saarinen, J., \& Leinonen, R. (2009). Sustainable Tourism Planning and Regional Development in Peripheries: A Nordic View. Scandinavian Journal of Hospitality and Tourism, 9 (4), 424-435

Knowd, I. (2006). Tourism as a Mechanism for Farm Survival. Journal of Sustainable Tourism, 14(1), 24-42.

Lazzeretti, L., \& Petrillo, C.S. (2006). Local Tourism Systems and Networking. Amsterdam: Elsevier.

Lee, J., Arnason, A., Nightingale, A., \& Shucksmith, M. (2005). Networking: Social Capital and Identities in European Rural Development. Sociologia Ruralis, 45(4), 269-283.

LofotenMat BA (2008). Utviklingsplan 2008-2012.

McGehee, N. G., \& Kim, K. (2004). Motivation for Agri-Tourism Entrepreneurship. Journal of Travel Research, 43, 161-170.

Moscardo, G. (2008). Sustainable tourism innovation: Challenging basic assumptions. Tourism and Hospitality Research, 8(1), 4-13.

OECD, (2001). Multifunctionality. Towards an analytical framework. Paris.

OECD, (2002). OECD Territorial Review: Siena. Paris. 
Oukumus, B., Oukumus, F., \& McKercher, B. (2007). Incorporating local and international cousines in the marketing of tourism destinations: The cases of Hong Kong and Turkey. Tourism Management, 28, 253-261

Pacciani, A. (2003). La Maremma Distretto Rurale. Un nuovo modello di sviluppo nella consapevolezza della propria identta'. Grosseto: Editrice "il mio Amico".

Pagni, R. (2002). Parco Regionale della Maremma. In R. Pagni, Il turismo e la valorizzazione delle aree protette. Analisi dell'esperienza Toscana. Pontassieve: Regione Toscana/Irpet.

Petrini, C. (2003). Slow Food. Le ragioni del gusto. Laterza.

Plummer, R., Telfer, D., \& Haimoto, A. (2006). The Rise and Fall of the Waterloo-Wellington Ale Trail: A Study of Collaboration within the Tourism Industry. Current Issues in Tourism, 9(3), 190-205.

Provincia di Grosseto (2009, September 7). Comunicato stampa: Polo tecnologico multidisciplinare e Centro per la qualita'. Retrieved from

http://www.provincia.grosseto.it/pages/notizia.jsp?anno=2009\&mese=8\&idNotizi $\underline{\mathrm{a}=39358}$

Quan, S., \& Wang, N. (2004). Towards a structural model of the tourist experience: an illustration from food experiences in tourism. Tourism Management, 25, 297-305.

Ray, C. (1998). Culture, Intellectual Property and Territorial Rural Development. Sociologia Ruralis, 38(1), 3-20.

Richards, G. (2002). Gastronomy: an essential ingredient in tourism production and consumption? In A.M. Hjalager, \& G. Richards (Eds.). Tourism and Gastronomy. London: Routledge

Rønningen, K., Fjeldalvi, E., \& Flø, B.E. (2005). Multifunskjonalt landbruk - hva slags legitimitet har fellesgodeproduksjon innad landbrukssektoren? Trondheim: Centre for Rural Research. Retrieved from http://www.bygdeforskning.no/dynamisk/Publikasjoner_PDF/r.8.05\%20rev.utgav e.pdf

Saarinen, J. (2007), Tourism in Peripheries: the Role of Tourism in Regional Development in Northern Finland. In Müller, D.K., \& Jansson, B. (Eds). Tourism in Peripheries: Perspective from the Far North to South. Cabi.

Scarpato, R. (2002a). Gastronomy as a tourist product: the perspective of gastronomy studies. In A.M. Hjalager, \& G. Richards (Eds.). Tourism and Gastronomy. London: Routledge

Scarpato, R. (2002b). Sustainable gastronomy as a tourist product. In A.M. Hjalager, \& G. Richards (Eds.). Tourism and Gastronomy. London: Routledge 
Shaw, G., \& Williams. A. (2009). Knowledge transfer and management in tourism organisations: An emerging research agenda. Tourism Management, 30 (3), 325335

Slow Food (2010, February 17). University of Gastronomic Sciences. Retrieved from: http://www.unisg.it/

Sonnino, R. (2004). For a 'Piece of Bread'? Interpreting Sustainable Development through Agritourism in Southern Tuscany. Sociologia Ruralis, 44(3), 285-300.

Telfer, D. J., \& Wall, G. (1996). Linkages between tourism and food production. Annals of Tourism Research, 23(3), 635-653.

Tellstrom, R., Gustafsson, I-B, \& Mossberg, L. (2005). Local Food Cultures in the Swedish Rural Economy. Sociologia Ruralis, 45(4), 346-359.

Toccaceli, D. (2006). Il Distretto Rurale della Maremma 1996-2006: come si forma un distretto rurale. AgriRegioniEuropa 2(6). Retrieved from: http://agriregionieuropa.univpm.it/dettart.php?id_articolo=147

Tovey, H. \& Mooney, R. (2006). Sisth Framework Programme Priority 7. Citizens and Governance in a Knowledge Based Society. project CORASON. Proposal nr 506049 Final Report. Trinity College Dublin. Retrieved from: http://www.corason.hu/download/final_report.pdf

Tregear, A. (2003). From Stilton to Vimto: Using Food History to re-think Typical Products in Rural Development. Sociologia Ruralis, 43(2), 91-107.

Tregear, A. (2005). Lifestyle. Growth, or Community Involvement? The Balance of Goals of UK Artisan Food Producers. Entrepreneurship \& Regional Development, 17, 1-15.

Tregear, A., Arfini, F., Belletti, G., \& Marescotti, A. (2007). Regional foods and rural development: The role of product qualification. Journal of Rural Studies, 23, $12-22$.

Van der Ploeg, J. D., Renting, H., Brunori, G., Knickel, K., Mannion, J., Mardsen, T., de Roest, K., Sevilla-Guzman, E., \& Ventura F. (2000). Rural Development: From Practices and Policies towards Theory. Sociologia Ruralis, 40(4), 391-408.

Van der Ploeg, J. D., \& Roep, D. (2003). Multifunctionality and rural development: the actual situation in Europe. In G. van Huylenbroeck \& G. Durand (Eds.). Multifunctional agriculture: a new paradigm for European agriculture and rural development? Aldershot, Ashgate.

Van Huylenbroeck, G. \& G. Durand (2003). Multifunctional agriculture: a new paradigm for European agriculture and rural development. Aldershot, Ashgate. 
Woodside, A.G. (2010). Bridging the chasm between survey and case study research: Research methods for achieving generalization, accuracy and complexity. Industrial Marketing Management, 39 (1), January 2010, 64-75.

Yin, R. K. (2003). Case Study Research. Design and Methods. Sage. 